\title{
Jual Beli Kredit Dalam Perspektif Ekonomi Islam
}

\author{
Rachmad Risqy Kurniawan, SEI, MM \\ Sekolah Tinggi Ilmu Ushuluddin Darul Qur’an Mulia, Bogor \\ Email: rah.rizqy@gmail.com \\ Kharisma Putri \\ Sekolah Tinggi Ilmu Ushuluddin Darul Qur’an Mulia, Bogor \\ Email : Mputputkharisma123@gmail.com
}

\begin{abstract}
This study aims to explain the buying and selling of credit in the perspective of Islamic economics which is built based on the interpretation of the verses that are the source and foundation of Islamic economics. This research is library research with maudu'i (thematic) interpretation method and tahlili (analytic) interpretation method. The results of this study indicate the law of permissibility (permissible) of buying and selling credit based on the generality of buying and selling in Surah Al-Baqarah Verse 275 with syar'i limitations, namely the agreed price and recording transactions in accordance with Surah An-Nisaa verse 29 and Al-Baqarah Verse 282.
\end{abstract}

Keywords: Buying and Selling of Credit, Islamic Economics

\begin{abstract}
Abstrak: Penelitian ini bertujuan untuk menjelaskan jual beli kredit dalam perspektif ekonomi Islam yang dibangun berdasarkan penafsiran ayat-ayat yang menjadi sumber dan landasan ekonomi Islam. Penelitian ini merupakan penelitian kepustakaan (library research) dengan metode penafsiran maudu'i (tematik) dan metode penafsiran tahlili (analitik). Hasil penelitian ini menunjukkan hukum kebolehan (mubah) jual beli kredit berdasarkan dengan keumuman jual beli dalam Surat Al-Baqarah Ayat 275 dengan batasan-batasan syar'i yaitu harga yang disepakati dan pencatatan transaksi sesuai dengan Surat An-Nisaa ayat 29 dan Al-Baqarah Ayat 282.
\end{abstract}

Kata Kunci: Jual-beli Kredit, Ekonomi Islam

\section{Pendahuluan}

Islam menjadikan Al-Quran dan Hadist sebagai landasan hidup bagi seluruh pemeluknya termasuk dalam hal memenuhi kebutuhan hidupnya, antara lain dengan membolehkan jual beli sebagaimana Firman Allah SWT dalam Surat Al-Baqarah Ayat 275 berikut:

$$
\text { وَاَحَلَّ اللُهُ الْبَيْعَ }
$$

Artinya: Padahal Allah telah menghalalkan jual beli

Namun jual beli yang terjadi di masyarakat saat ini, tidak hanya menggunakan transaksi jual beli tunai melainkan juga non-tunai, yaitu cara menjual barang dengan 
pembayaran secara tidak tunai (pembayaran ditangguhkan atau diangsur) atau dikenal dengan jual beli kredit. ${ }^{1}$

Hal ini masih sering terjadi di masyarakat disebabkan beberapa faktor, salah satunya karena adanya kebutuhan manusia yang mendesak sementara itu tidak mempunyai uang tunai sehingga alternatif membeli dengan cara kredit menjadi pilihan. $^{2}$ Adanya jenis pembayaran secara kredit ini memang memudahkan masyarakat dalam memenuhi kebutuhannya. Namun demikian, jual beli kredit juga menuai pro dan kontra jika dilihat dari perspektif ekonomi Islam, yaitu terkait hukum kebolehan dan keharamannya. Adapun pendapat yang membolehkan jual beli kredit menyandarkan pendapatnya pada keumuman hukum jual beli yaitu mubah, karena jual beli kredit termasuk jual beli maka jual beli kredit juga dihukumi mubah atau boleh, sementara itu pendapat yang mengharamkan jual beli kredit mendasarkan pendapatnya pada keharaman tambahan dalam harga jual beli kredit akibat waktu diangsurnya pembayaran dalam jual beli kredit. ${ }^{3}$

Berdasarkan fenomena diatas, peneliti ingin mengkaji lebih dalam bagaimana jual beli kredit dalam perspektif ekonomi Islam berdasarkan metode penafsiran maudu'i (tematik) dan metode penafsiran tahlili (analitik) melalui sejumlah sumber primer antara lain beberapa kitab tafsir dan sumber sekunder artikel ilmiah terkait dengan masalah penelitian ini, sehingga penelitian ini dapat menjadi dasar dan landasan operasional jual beli kredit di tengah masyarakat.

\section{Jual Beli Kredit Dalam Perspektif Ekonomi Islam: Hukum dan Batasannya}

Ekonomi Islam dibangun berdasarkan syumuliyah dan mutakamilah (komprehensif dan tuntas) syariat Islam, sehingga dalam prakteknya selalu berkaitan dengan batasan-batasan serta aturan yang telah ditetapkan oleh Allah SWT. Begitu pula dalam merumuskan hukum jual beli kredit harus berdasarkan aturan syariat yang sudah ditetapkan Allah SWT. Dalam prakteknya jual beli kredit atau secara diangsur sudah di praktekkan semenjak masa Rasulullah SAW ${ }^{4}$. Adapun dasar hukum kebolehan jual beli kredit berdasarkan keumuman Surat Al-Baqarah Ayat 275 berikut:

$$
\text { وَاَحَلَّ اللُلهُ الْبِيْعَ }
$$

Artinya: Padahal Allah telah menghalalkan jual beli

Rasyid Ridha menafsirkan ayat ini bahwa Allah SWT menghalalkan keuntungan yang diperoleh dalam perdagangan, baik dalam pembelian maupun dalam penjualan. Ayat ini juga menegaskan tambahan dalam riba dan jual beli tidaklah sama, baik secara praktek, bahaya dan manfaatnya. Allah SWT tidak akan mengharamkan sesuatu kecuali mengandung bahaya, dan tidak menghalalkan sesuatu kecuali yang

1 Badan Pengembangan dan Pembinaan Bahasa, Kamus Besar Bahasa Indonesia (KBBI). [Online]. Available at: http://kbbi.web. 2021.

${ }^{2}$ Tri Hasrida Yanti, Faktor-Faktor Yang Mempengaruhi Minat Masyarakat Terhadap Jual Beli Kredit Ditinjau Dari Ekonomi Islam (Studi Kasus Dusun Karang Agung Desa Negara Nabung Kecamatan Sukadana Kabupaten Lampung Timur) (Institut Agama Islam Negeri (IAIN) Metro. 2018)

${ }^{3}$ Nur Fathoni, Konsep Jual Beli dalam Fatwa DSN-MUI. Economica. Vol IV. Edisi 1. 2013

${ }^{4}$ Masruri, Hukum Jual Beli Bertempo Dalam Perspektif Hadits-Hadits Al-Kutub As-Sittah. Other thesis, IAIN Salatiga, 2019 
memberikan manfaat. ${ }^{5}$ Sementara itu Ibnu Katsir dalam kitab tafsirnya menafsirkan ayat ini sebagai penolakan terhadap mereka yaitu orang kafir yang mengagap sama antara jual beli dan riba atau terhadap apa yang mereka katakan. Padahal sesungguhnya mereka mengetahui perbedaan hukum antara keduanya (QS. An-Nisaa Ayat 161), maka melalui ayat ini Allah menegaskan perbedaan hukum diantara jual beli dan riba. Yaitu hukum jual beli adalah halal sedangkan hukum riba adalah haram. ${ }^{6}$

Adapun menurut tafsir jalalain, ayat وَاَحَلَّ اللُهُ الْبَيْع merupakan penegasan kebalikan dari persamaan yang mereka katakan itu artinya apa yang mereka persamakan itu secara hukum bertolak belakang. ${ }^{7}$

Tidak ada pertentangan di antara para ulama terkait asababun nuzul dari para mufassir, bahwa ayat ini turun sebagai penegasan atas praktik riba yang dilakukan oleh penduduk Mekah dengan penduduk Thaif dan penegasan Allah SWT mengenai perbedaan hukum antara jual beli dan riba. ${ }^{8}$

Berdasarkan paparan diatas maka, keuntungan yang diperoleh dalam proses jual beli baik tunai maupun tidak tunai atau kredit asalkan bersumber dari kegiatan jual beli maka hukumnya adalah boleh dan sebaliknya seluruh pendapatan atau keuntungan yang didapatkan dari proses utang-piutang dengan tambahan riba hukumnya haram.

Kesimpulan diatas diperkuat dengan Surat An-Nisaa Ayat 29 berikut ini:

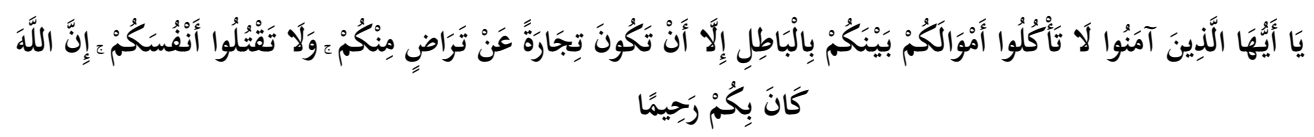

Artinya: Hai orang-orang yang beriman, janganlah kamu saling memakan harta sesamamu dengan jalan yang batil, kecuali dengan jalan perniagaan yang berlaku dengan suka sama-suka di antara kamu. Dan janganlah kamu membunuh dirimu; sesungguhnya Allah adalah Maha Penyayang kepadamu.

Berdasarkan ayat diatas maka semua transaksi jual beli atas dasar suka sama suka dibolehkan oleh Allah SWT termasuk juga jual beli kredit jika berdasarkan prinsip kerelaan kedua pihak atau suka sama suka, terkait prinsip suka sama suka ini menjadi satu syarat penting dalam transaksi jual beli kredit, karena harga yang dibayarkan dengan diansur atau kredit selalu lebih mahal dari pada jika dibayarkan secara tunai, maka harga dalam jual beli kredit harus disepakati dengan suka sama suka sehingga tidak ada pihak yang dirugikan.

${ }^{5}$ Muhammad Rasyid Ridha, Tafsir al-Qur’an al-Hakim (Tafsir al-Manar), Jilid IV, h.122 Dar Al-Je il: Mesir., 1367 dalam Lilis Maulida, Studi Komparatif Penafsiran Ayat-Ayat Tentang Riba Dalam Tafsir Al-Manar Dan Tafsir Ibnu Katsir, (UIN Syarif Hidayatullah: 2008)

${ }^{6}$ Ibnu Katsir, Tafsir al-Qur'an al-Adzim (Beirut : Daar al-Fikr, 1923), Juz. I, h. 402 dalam Lilis Maulida, Studi Komparatif Penafsiran Ayat-Ayat Tentang Riba Dalam Tafsir Al-Manar Dan Tafsir Ibnu Katsir, (UIN Syarif Hidayatullah: 2008)

${ }^{7}$ Imam Jalaluddin Al-Mahally dan Imam Jalaluddin As-Suyutti, Tafsir Jalalain Berikut Asbab An-Nuzulnya, Bandung,: Sinar Baru, 1990

${ }^{8}$ Ahmad Muzhaffar, Dkk., Riba dalam Al-Quran: Sebuah Kajian Antropologis, Al-Mazahib, Volume 3, Nomer 1, Juni 2015 
Dalam kitab tafsir Ibnu Katsir, firman Allah Kecuali dengan jalan perniagaan yang berlaku dengan suka sama suka diantara kalian.” Ditafsirkan bahwa jangan melakukan usaha-usaha yang haram dalam mendapatkan harta, akan tetapi ambilah dari perniagaan yang berdasarkan kerelaan dari kedua belah pihak. ${ }^{9}$ Maka sesungguhnya ayat ini menegaskan bahwa jual beli batil yang dilarang Allah SWT itu sangat spesifik diatur, sehingga kaidah dalam bermuamalah itu bukan mencari apa yang dihalalkan namun apa saja yang diharamkan, karena sesungguhnya dalam muamalah itu semua dibolehkan kecuali yang dilarang sesuai dengan kaidah 10 الأصل في العقود والمعاملات الإباحة ولا يحرم منها إلا ما ورد الشرع بتحريمه

Dari ayat yang ini, Imam syafi'i berhujjah bahwa jual beli tidak sah kecuali dengan adanya penerimaan. Karena itu menunjukan kerelaan kedua belah pihak. ${ }^{11}$

Dalam kitab tafsir As-Sa'di, kerelaan itu dari kedua belah pihak, dan adanya opsi untuk membatalkan atau mengembalikan barang atau harga yang diperdagangkan jika ditemukan kesalahan dikemudian hari, untuk itu maka pengetahuan yang lengkap terhadap barang dan harga menjadi syarat utama mendapatkan kerelaan kedua belah pihak, supaya tidak terjadi بيع القمار (gambling) atau asymmetric information بيع الغرر

Menurut al-Baghwy dalam tafsirnya, kerelaan tersebut dapat ditunjukkan dengan kebaikan jiwa kedua belah pihak, yang mana tidak ada unsur ingin menipu maupun berkhianat. ${ }^{13}$

Menurut al qurtuhubi yang dimaksud dengan عَنْ تَرَاضٍ مِنْكُمْ adalah unsur persetujuan kedua belah pihak yang meliputi adanya kebolehan untuk memilih dan ada kompromi setelah pilihan diputuskan. ${ }^{14}$

Adapun menurut ath-thabary, yang dimaksud dengan عَنْ تَرَاضٍ مِنْكُمْ adalah kerelaan kedua belah pihak atas keuntungan yang didapatkan penjual, sehingga pengetahuan harga dari barang serta keuntungan menjadi syarat kerelaan tersebut. ${ }^{15}$

Seperti yang telah dijelaskan diatas, bahwa jual beli kredit dibolehkan. Selama ada kesepakatan diantara keduanya (antara penjual dan pembeli) mengenai harga dan waktu akhir batas pembayaran. Dan keduanya harus saling menepati janji, dalam artian

${ }^{9}$ Ibnu Katsir, Tafsir al-Qur'an al-Adzim (Beirut : Daar al-Fikr, 1923)

${ }^{10}$ Kaidah ini adalah kaidah yang disepakati oleh jumhur ulama dari 4 madzhab yaitu hanafiyah, malikiyah, syafiiyah, dan hanabilah sebagaimana ditulis dalam sumber utama 4 madzhab tersebut antara

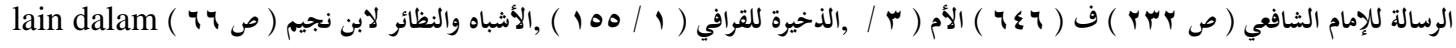

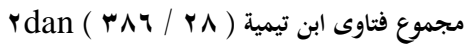

${ }^{11}$ Ibnu Katsir, Tafsir al-Qur’an al-Adzim (Beirut : Daar al-Fikr, 1923)

${ }^{12}$ Syaikh Abdurrahman bin Nashir as-Sa'di . Taisirul Karimirrahman fi Tafsiri Kalamil Mannan. Cet. I; Baerut: Dar Ibn Hazm, 2003.

13 Al-Baghawiy, Al-Husain bin Masúd. “Ma’alim al-Tanzil",. Jilid. 1. Riyad: Dar al-Taybah, 1409.

14 Qurtubi, (al)Ahmad Muhammad bin. Al-Jāmi’ Li Ahkām Al-Qur’an. Bairut-Libnan: Muassasah al-Risālah, 2006.

15 Al-Ṭhabarī , Abu Ja far Muḥammad Ibn Jarīr Ibn Yazīd Ibn Kathir Ibn Gālib . Jāmi’u alBayān fī Ta`wīli al-Qur’ān (Beirut: Daarul Kitab, 1412 H/1992 M) 
penjual tidak boleh melebihkan harga yang telah disepakati, dan pembeli harus membayar pada waktu yang telah disepakati keduanya. Agar terjadi kriteria dan syarat diatas yaitu harga dan waktu pembayaran yang disepakati maka transaksi jual beli kredit harus dicatat, adapun pencatatan transaksi non tunia telah Allah ajarkan sebagaimana firman Allah SWT dalam surat Al-Baqarah Ayat 282:

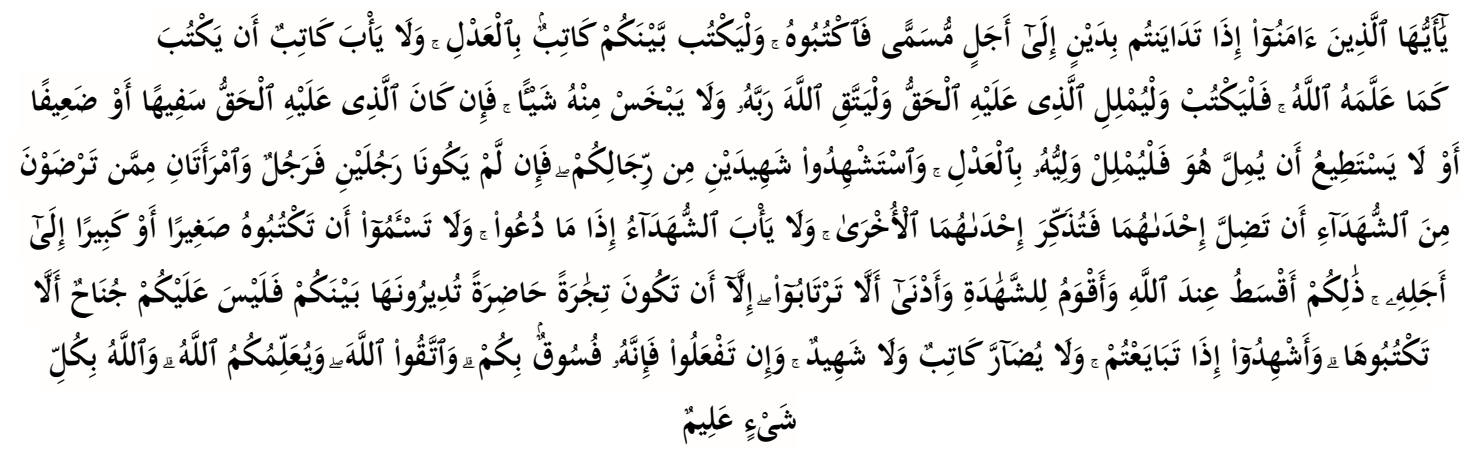

Artinya : "Hai orang-orang yang beriman, apabila kamu bermu'amalah tidak secara tunai untuk waktu yang ditentukan, hendaklah kamu menuliskannya. Dan hendaklah seorang penulis di antara kamu menuliskannya dengan benar. Dan janganlah penulis enggan menuliskannya sebagaimana Allah mengajarkannya, meka hendaklah ia menulis, dan hendaklah orang yang berhutang itu mengimlakkan (apa yang akan ditulis itu), dan hendaklah ia bertakwa kepada Allah Tuhannya, dan janganlah ia mengurangi sedikitpun daripada hutangnya. Jika yang berhutang itu orang yang lemah akalnya atau lemah (keadaannya) atau dia sendiri tidak mampu mengimlakkan, maka hendaklah walinya mengimlakkan dengan jujur. Dan persaksikanlah dengan dua orang saksi dari orang-orang lelaki (di antaramu). Jika tak ada dua oang lelaki, maka (boleh) seorang lelaki dan dua orang perempuan dari saksi-saksi yang kamu ridhai, supaya jika seorang lupa maka yang seorang mengingatkannya. Janganlah saksi-saksi itu enggan (memberi keterangan) apabila mereka dipanggil; dan janganlah kamu jemu menulis hutang itu, baik kecil maupun besar sampai batas waktu membayarnya. Yang demikian itu, lebih adil di sisi Allah dan lebih menguatkan persaksian dan lebih dekat kepada tidak (menimbulkan) keraguanmu. (Tulislah mu'amalahmu itu), kecuali jika mu'amalah itu perdagangan tunai yang kamu jalankan di antara kamu, maka tidak ada dosa bagi kamu, (jika) kamu tidak menulisnya. Dan persaksikanlah apabila kamu berjual beli; dan janganlah penulis dan saksi saling sulit menyulitkan. Jika kamu lakukan (yang demikian), maka sesungguhnya hal itu adalah suatu kefasikan pada dirimu. Dan bertakwalah kepada Allah; Allah mengajarmu; dan Allah Maha Mengetahui segala sesuatu.

Sufyan Ats-tsauri mengatakan : dari Ibnu Abi Najih, dari Mujahid, dari Ibnu Abbas, tentang firman-Nya :

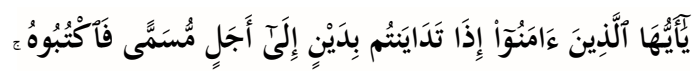

“Hai orang-orang yang beriman, apabila kamu bermu'amalah tidak secara tunai untuk waktu yang ditentukan, hendaklah kamu menuliskannya”. Ia mengatakan ayat ini turun berkenaan dengan transaksi jual beli salam (dengan cara pesanan) sampai batas waktu yang tidak diketahui. Qatadah mengatakan dari Abu Hasan Al A'raj dari Ibnu Abbas r.a, ia berkata : “ aku bersaksi bahwa jual beli salaf sampai satu batas waktu 
tertentu yang ada jaminannya, dibolehkan dihalalkan oleh Allah swt.”. kemudian Ia membaca :

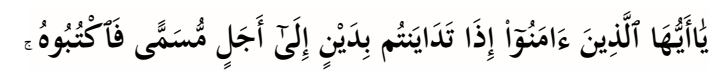

HR. Al-Bukhori. Disebutkan juga dalam Ash-Shohihain dari Ibnu Abbas ra, Pada saat Nabi saw datang ke Madinah, penduduk disana terbiasa jual beli buah-buahan dengan cara memesan unuk jangka waktu dua atau tiga tahun. Maka Rasulallah saw Bersabda :

$$
\text { من سلف فليسلف في كيل معلوم ووزن معلوم إلي أجل معلوم }
$$

"Barang siapa memesan, maka hendaklah ia memesan dalam jumlah takaran yang diketahui (oleh kedua belah pihak), dalam timbangan yang diketahui (oleh kedua belah pihak), serta hingga jangka waktu yang diketahui (oleh kedua belah pihak). ${ }^{\mathbf{1 6}}$

“فَكْيُبُوه menghilangkan pertikaian nantinya. ${ }^{17}$

” Dan hendaklah seorang penulis diantara kamu menulis dengan benar." Dalam artian penulisnya harus adil tanpa berpihak pada salah satu saja. $^{18}$

Dari penafsiran diatas dijelaskan, bahwa seseorang yang menuliskan hendaklah menulis dengan adil dan benar, tidak berat sebelah, sehingga pihak lain merasa terdzolimi, tidak menuliskan selain apa yang telah disepakati oleh keduanya, tidak menambahkan dan tidak menguranginya.

Dan janganlah seorang penulis menolak untuk menuliskannya sebagaimana Allah telah mengajarkannya. Yaitu apabila kita mengetahui ilmunya, bisa membantu untuk menuliskannya, maka wajib bagi kita untuk menolongnya Firman Allah tentang tolong menolong dalam kebaikan :

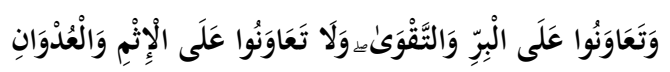

Artinya “ Dan tolong-menolonglah kamu dalam (mengerjakan) kebajikan dan takwa,dan jangan tolong-menolong dalam berbuat dosa dan pelanggaran.”

Dalam hadits lain disebutkan :

$$
\text { مَنْ كتم عِلْماً يعلمه ألجم يوم القيا مة بلجام من نار }
$$

“ Barang siapa yang menyembunyikan suatu ilmu yang diketahuinya, maka pada hari kiamat kelak akan dipasangkan padanya tali kekang dari api neraka.” Mujahid Atha' menerangkan, “ wajib bagi yang bisa menuliskan untuk menuliskannya.”

\footnotetext{
${ }^{16}$ Ibnu Katsir, Tafsir al-Qur’an al-Adzim (Beirut : Daar al-Fikr, 1923)

${ }^{17}$ Imam Jalaluddin Al-Mahally dan Imam Jalaluddin As-Suyutti, Tafsir Jalalain Berikut Asbab An-Nuzulnya, Bandung,: Sinar Baru, 1990

${ }^{18}$ Muhammad Ali Al-Sabuni, Shafwa Al-Tafsir Jilid I, (Beirut 2019) 


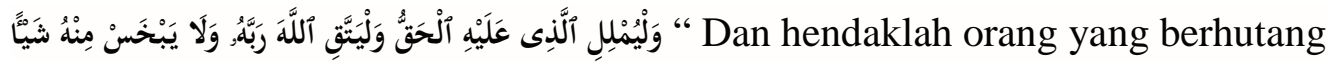
Itu mendiktekan, dan hendaklah dia bertaqwa kepada Allah, Tuhannya, dan janganlah ia mengurangi sedikitpun daripadanya.”

Hendaklah orang yang berhutang mendiktekan, karena dialah yang dipersaksikan, maka hendaklah diakuinya agar diketahuinya kewajibannya, dan hendaklah ia takut kepada Allah dalam mendiktekannya dan janganlah mengurangi sedikitpun dari hutangnya itu. ${ }^{19}$

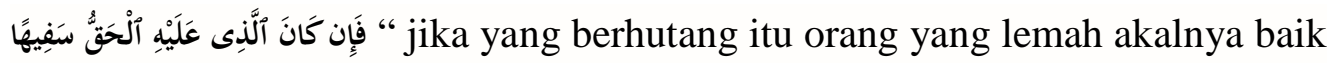

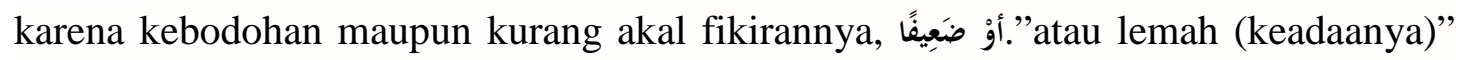
karena masih kecil atau gila. Atau dia sendiri tidak mampu فَلْيُمْنِ ${ }^{20}$ “ maka hendaklah walinya mendiktekan dengan benar”. Maka wali mendiktekan hutangnya dengan tidak menambahkan dan menguranginya. ${ }^{21}$

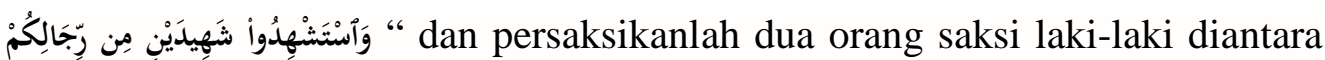

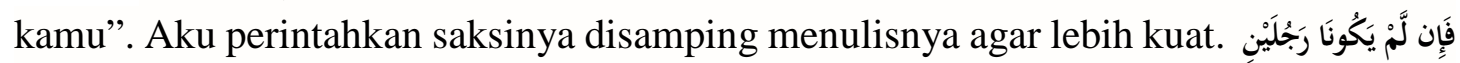

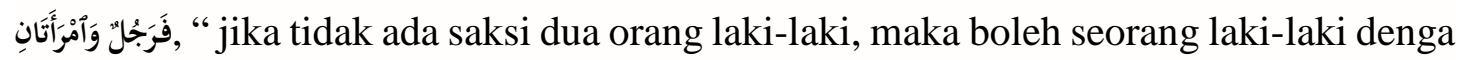
dua orang perempuan.” Ini hanya berlaku dalam permasalahan dan upaya untuk mendapatkannya. Dua Wanita disamakan dengan seorang laki-laki, karena Wanita lemah akal. Sebgaimana yang dinyatakan oleh imam muslim, dalam kitab shahihnya, dar abu Hurairah ra, dari nabi saw, beliau bersabda :

"Wahai sekalian kaum Wanita, bersedekahlah kalian dan banyak-banyaklah beristighfar. Karena aku melihat kalian sebagai penghuni neraka yang paling banyak jumlahnya." Seorang Wanita pun bertanya, "wahai rasulallah, kenapa kami menjadi penghuni nerakayang paling banyak jumlahnya ?” beliau menjawab "karena kalian sering melaknat dan kufur(tidak bersyukur) terhadap suami. Aku belum pernah melihat orang yang lemah akal dan agamanya dapat mengalahkan orang yang berakal selain daripada kalian.” Wanita tersebut bertanya lagi," Wahai Rasulallah apa maksud lemah akal dan agamanya?. Beliau menjawab,” lemah akal karena kesaksian seorang wanita sepadan dengan kesaksian dua orang laki-laki. Dan lemah agamanya karena tidak shalat beberapa malam/hari (karena haid) serta berbuka (tidak puasa) pada bulan ramadhan. Inilah kelemahannya dalam hal agama. ${ }^{22}$

Hendaklah yang menjadi saksi diantara kamu adalah yang disukai disebabkan agama dan kejujurannya. Saksi-saksi Wanita jadi berganda, supaya Ketika seseorang lupa akan kesaksian disebabkan kurang akal dan lemahnya ingatan mereka. (maka yang lain (yang ingat) akan mengingatkan kawannya), yakni yang lupa. Ada yang membaca 'tudzkir' dan ada yang dengan tasydid 'tudzakkir'. Jumlah dari idzkar menempati kedudukan sebagai illat, artinya untuk mengingatkannya jika ia lupa atau berada di ambang kelupaan, karena itulah yang menjadi sebabnya. Menurut satu qiraat 'in'

${ }^{19}$ Imam Jalaluddin Al-Mahally dan Imam Jalaluddin As-Suyutti, Tafsir Jalalain Berikut Asbab An-Nuzulnya, Bandung,: Sinar Baru, 1990

${ }^{20}$ Ibnu Katsir, Tafsir al-Qur'an al-Adzim (Beirut : Daar al-Fikr, 1923)

${ }^{21}$ Muhammad Ali Al-Sabuni, Shafwa Al-Tafsir Jilid I, (Beirut 2019)

${ }^{22}$ Ibnu Katsir, Tafsir al-Qur’an al-Adzim (Beirut : Daar al-Fikr, 1923) 
syarthiyah dengan baris di bawah, sementara 'tudzakkiru' dengan baris di depan sebagai jawabannya. ${ }^{23}$

“dan janganlah saksi-saksi itu menolak apabila dipanggil.” Para saksi tidak boleh menahan dirinya untuk memberi kesaksian jika mereka diminta untuk melakukannya. ${ }^{24}$

“dan janganlah kamu bosan menuliskannya, untuk batasan waktunya baik (utang itu) kecil maupun besar.” Ini termasuk perintah dari Allah swt. Yaitu, perintah untuk menulis yang benar, baik kecil maupun besar, dia berfirman “ dan janganlah kamu jemu.” Yakni, jangan kalian bosan untuk menuliskan yang benar dalam kondisi apapun, baik hutang itu sedikit, terlebih bila banyak. Sampai

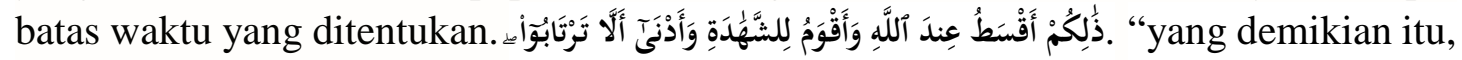
lebih adil disisi Allah dan lebih menguatkan persaksian dan lebih mendekatkan kamu kepada Tindakan ketidak raguan," maksudnya, apa yang kami perintahkan kepada kalian ini, yaitu menulis yang benar apabila dengan system tempo, adalah, “ lebih adil disisi Allah,” yakni, lenih lurus. "Dan lebih menguatkan persaksian,” yakni lebih menguatkan saksi ketika ia meletakan catatannya kemudian dilihat olehnya hingga ia teringat Kembali atas kesaksiannya. Hal itu disebabkan karena ada kemungkinan ia lupa jika tidak menuliskannya sebagaimana yang seringkali terjadi. "dan lebih mendekatkan kamu kepada ketidak raguan,” maksudnya, lebih dapat menghilangkan keraguan. Sehingga, Ketika terjadi perselisihan kalian dapat merujuk pda catatan yang telah kalian tulis, hinga catatan itupun memecahkan perselisihan tanpa ada keraguan. ${ }^{25}$

إِلَّ أَن تَكُونَ تِجُرَةً حَاضِرَةً نُدِيرُونَهَا بِيْنَكُمْ kecuali jika itu perdagangan tunai yang kamu jalankan diantara kamu, jika jual beli itu secara tunai, yakni yang kamu pegang dan

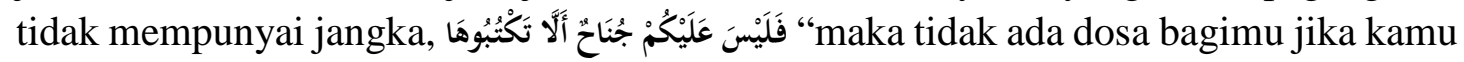
tidak menuliskannya” maka tidak apa-apa dengan tidak menuliskannya, untuk

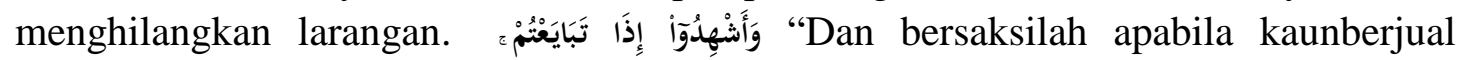
beli,”yaitu bersaksilah kamu secara mutlak, baik jula beli secara langsung ataupun dengan cara berhutang, karena itu akan menjauhkanmu dari perselisihan dan perbedaan. “dan janganlah penulis dipersulit dan begitu juga saksi” yakni

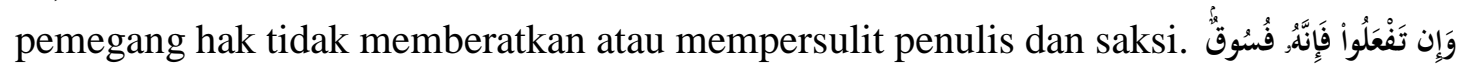

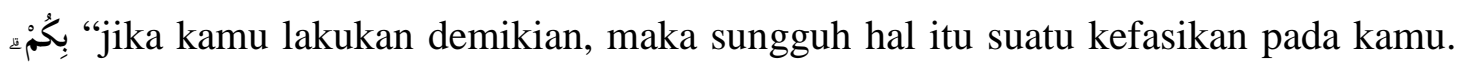
Jika kamu melakukan apa dilarang, maka kamu telah berdosa dengan tidak mentaati

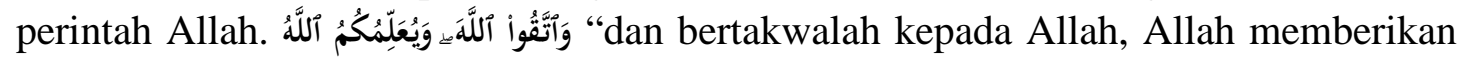
pengajaran kepadamu”. Takutlah kepada Allah, yakni dengan menjalankan perintahNya dan menjauhi larangan_Nya, Karena Tuhan telah memberimu ilmu yang bermanfaat yang membawa kepada kebahagiaan dunia dan akhirat. ${ }^{26}$

Berdasarkan paparan diatas, maka kewajiban untuk mencatat transaksi jual beli kredit bertujuan agar tidak ada kelebihan bayar mapun kurang bayar dari harga yang

\footnotetext{
${ }^{23}$ Imam Jalaluddin Al-Mahally dan Imam Jalaluddin As-Suyutti, Tafsir Jalalain Berikut Asbab An-Nuzulnya, Bandung,: Sinar Baru, 1990

24 Muhammad Ali Al-Sabuni, Shafwa Al-Tafsir Jilid I, (Beirut 2019)

${ }^{25}$ Ibnu Katsir, Tafsir al-Qur’an al-Adzim (Beirut : Daar al-Fikr, 1923)

${ }^{26}$ Muhammad Ali Al-Sabuni, Shafwa Al-Tafsir Jilid I, (Beirut 2019)
} 
sudah disepakati dalam jangka waktu yang sudah disepakti juga sehingga tidak ada pihak yang terdzolimi maupun dirugikan.

\section{Penutup}

Ekonomi Islam yang dibangun diatas prinsip syariah Islam sesungguhnya sudah mengakomodasi seluruh kegiatan ekonomi atau muamalah manusia, termasuk hukum jual beli kredit, karena ekonomi Islam merupakan sistem perekonomian berdasarkan Al-Quran dan Hadist, maka berdasarkan Al-Quran dan Hadist pula suatu transaksi ekonomi dapat dihukumi dibolehkan (mubah) atau dilarang (haram). Berdasarkan penelitian ini maka dapat disimpulkan bahwa jual beli kredit dalam persepektif ekonomi Islam dibolehkan dengan beberapa syarat yaitu berdasarkan prinsip kerelaan antara kedua belah pihak dan dan harus dicatat dengan pencatatan yang sudah dijelaskan dalam surat Al-Baqarah Ayat 282, hal ini untuk mewujudkan kemashlahatan dan menghindari kemudharatan sebagaimana tujuan dari syariat islam.

\section{Daftar Pustaka}

Al-Sabuni, Muhammad Ali, Shafwa Al-Tafsir, Beirut: Dar al Shabuni, 2019

Ilham, dan Herlinda sultan, Perspektif Ekonomi Islam Terhadap Jual Beli Secara Kredit (Studi Kasus Di Desa Tarramatekkeng Kec. Ponrang Selatan, Vol 2, No 1 (2019)

Badan Pengembangan dan Pembinaan Bahasa, Kamus Besar Bahasa Indonesia (KBBI). [Online]. Available at: http://kbbi.web. 2021.

Khaer, Misbakhul dan Ratna Nurhayati, Jual Beli Taqsith (Kredit) Dalam Perspektif Hukum Ekonomi Islam, Vol. 2 No. 1, AL MAQASHIDI : Jurnal Hukum Islam Nusantara, (2019)

Nahidloh, Shofiyun, Sistem Kredit Dalam Ekonomi Islam Tinjauan Tafsir Ahkam, Vol 1, No 1( Juli 2014)

Ilham Akbar Fatriansyah, Alif, Kajian Penelitian Tentang Hukum Jual Beli Kredit, Vol 33, No 1, (Mei 2021)

Tri Hasrida Yanti, Faktor-Faktor Yang Mempengaruhi Minat Masyarakat Terhadap Jual Beli Kredit Ditinjau Dari Ekonomi Islam (Studi Kasus Dusun Karang Agung Desa Negara Nabung Kecamatan Sukadana Kabupaten Lampung Timur) (Institut Agama Islam Negeri (IAIN) Metro. 2018)

Fathoni, Nur. Konsep Jual Beli dalam Fatwa DSN-MUI. Jurnal Economica. Vol IV. Edisi 1, 2013

Masruri, Hukum Jual Beli Bertempo Dalam Perspektif Hadits-Hadits Al-Kutub As-Sittah. Other thesis, IAIN Salatiga. 2019

Ridha, Muhammad Rasyid, Tafsir al-Qur'an al-Hakim (Tafsir al-Manar), Jilid IV, h.122 Mesir: Dar Al-Je`il, 1367

Lilis Maulida, Studi Komparatif Penafsiran Ayat-Ayat Tentang Riba Dalam Tafsir Al-Manar Dan Tafsir Ibnu Katsir, (Skripsi, UIN Syarif Hidayatullah, 2008)

Al-Mahally, Imam Jalaluddin dan Imam Jalaluddin As-suyutti, Tafsir Jalalain Berikut Asbab An-Nuzulnya, Bandung,: Sinar Baru, 1990 
Ahmad Muzhaffar, Dkk., Riba dalam Al-Quran: Sebuah Kajian Antropologis, AlMazahib, Volume 3, Nomer 1, Juni 2015

As-Sa'di, Syaikh Abdurrahman bin Nashir . Taisirul Karimirrahman fi Tafsiri Kalamil Mannan. Cet. I; Baerut: Dar Ibn Hazm, 2003.

Al-Baghawiy, Al-Husain bin Masúd. Ma’alim al-Tanzil,. Jilid. 1. Riyad: Dar alTaybah, 1409.

Qurtubi, Ahmad Muhammad, Al-Jāmi' Li Ahkām Al-Qur'an. Bairut-Libnan: Muassasah al-Risālah, 2006.

Al-Ṭhabarī , Abu Ja"efar Muhammad Ibn Jarīr Ibn Yazīd Ibn Kathir Ibn Gālib . Jāmi'u al-Bayān fì Ta 'wìli al-Qur 'ān (Beirut: Daarul Kitab, 1992 ) 